\title{
Dependent on dietary treatments of mothers, rats showed individual preference of diets containing ingredients produced with different cultivation strategies* $^{*}$
}

\author{
C. Yong ${ }^{1,4}$, U. Halekoh ${ }^{2}$, H. Jørgensen ${ }^{1}$ and C. Lauridsen ${ }^{1,3}$ \\ ${ }^{1}$ Department of Animal Health, Welfare and Nutrition, \\ ${ }^{2}$ Department of Genetics and Biotechnology, \\ Danish Institute of Agricultural Sciences, Research Centre Foulum \\ P.O. Box 50, 8830 Tjele, Denmark
}

(Received 4 July 2005; accepted 17 October 2005)

\begin{abstract}
Three diets were prepared with ingredients cultivated by each of three different farming systems, low input of fertilizer without pesticides (LIminusP), low input of fertilizer and high input of pesticides (LIplusP), and high input of fertilizer and high input of pesticides (HIplusP). A preference test was conducted to investigate whether rats could distinguish among the three iso-energetic and iso-nitrogeneous diets, and the influence of the mothers' diet was accordingly studied with regard to the food choice of the progeny. The experimental diets contained potatoes, carrots, peas, green kales, apples, and rapeseed oil and were formulated to meet the NRC requirements for growing rats. Rats were weaned from dams, which had been fed one of the experimental diets. For five days, rats $(n=27)$ had free access to each of the three diets, and consumption of each of the diets was recorded daily. Thereafter, rats were offered a standard laboratory chow until the test was repeated. The results indicated that the majority of the rats showed individual preference for the diets and behaved similarly on different experimental days $(\rho=0.63$ in repetition 1 and $\rho=0.73$ in repetition 2$)$ and in the two repetitions $(\tau=0.79)$. There was a significant interaction between diet choice and mothers' diet $(\mathrm{P}=0.04$ in repetition 1 and $\mathrm{P}=0.05$ in repetition 2): when mothers' diet was LIminusP, the LIminusP was among the preferred diets. However, when the mothers were fed LIplusP or HIplusP, the rats showed the lowest consumption of LIminusP.
\end{abstract}

KEY WORDS: preference test, diet choice, organic food, conventional food, rats

\footnotetext{
* Supported by the Danish Research Centre for Organic Farming and Food Systems (DARCOF) through the project: Organic food and health - a multigeneration animal experiment

${ }^{3}$ Corresponding author: e-mail: Charlotte.Lauridsen@agrsci.dk

${ }^{4}$ Present address: National Feed Engineering Technology Research Center, China Agricultural University, No. 2 Yuanmingyuan West Road, Haidian, Beijing 100094, P. R. China
} 


\section{INTRODUCTION}

There has been a marked increase in the demand for organic food over the past decade especially in some European countries (Woese et al., 1997; Schifferstein and Ophuis, 1998). Because organic food is grown without the aid of chemicalsynthetic pesticides and largely without the use of readily soluble mineral fertilizers, many people believe that organic food is of better quality, healthier and more nutritious than conventional ones (Williams, 2002). However, no commonly accepted evidences have so far clearly shown any significant differences between organic and conventional foods.

Numerous studies (as reviewed by Woese, 1997; Worthington, 1998; Brandt and Mølgaard, 2000; Williams, 2002) have been conducted to investigate differences between organic and conventional foods by analysing their chemical compositions, but very few nutrient compositional differences have been reported (Brandt and Mølgaard, 2000). Furthermore, the findings from some data provide conflicting conclusions (Wolfson and Shearer, 1981; Warman and Havard, 1997). The question whether chemical analyses sufficiently define food quality has given rise to a series of studies based on holistic methods, e.g., determination of electrochemical parameters, animal feeding experiments and food preference tests (Plochberger, 1989; Plochberger and Velmirov, 1992; Johnson and Collier, 2001).

Food preference tests exploit advantage of the instinctive feeding behaviour of animals by allowing them to choose among several food samples. Laboratory rats are well suited for food preference test, and when choosing among foods of similar nutritional composition, a major determinant of choice by laboratory rats is the rate of nutrient intake (Johnson and Collier, 2001). Amongst other factors playing a role for the choose are the nutritional content of the food and the taste of the food, and rats' capability to identify and avoid poison and to choose the more nutritional feed, combined with their tendency to investigate new food sources, which results in manifold and flexible feeding behaviour. Investigations concerning essential and/or dangerous contents using laboratory rats are based on these characteristics (Fromentin and Nicolaidis, 1996; Koehnle et al., 2003), which has proven efficient (Benett and Henderson, 1972). Some food preference tests with various bread, common beets, beet roots, carrots, apples, and wheat have shown that rats were able to discriminate between organic and conventional products (Plochberger, 1989; Plochberger and Velmirov, 1992; Mäder et al., 1993). However, in these studies, preference tests were carried out with single food items, and according to our knowledge, no studies are available in which complete diets based on similar distribution of food items of different cultivation systems have been compared in preference tests with rats. In addition, only few animal studies (Pfeiffer, 1969; Plochberger and Velmirov, 1992) are available which have taken 
into consideration the influence of cultivation methods of mothers' diet, when studying the food choice by the progeny, when given access to diets based on organic and conventional products, although Benett and Henderson (1972) found that weanling rats actively seek and preferentially ingest the diets their mothers ate during the nursing period, even if the diet was relatively unpalatable.

The present study was conducted to investigate whether rats could distinguish among three iso-caloric and iso-nitrogeneous diets composed of ingredients, which were cultivated in three different farming systems, respectively, when the mothers were provided one of the experimental diets.

\section{MATERIAL AND METHODS}

\section{Animals}

The rats in this experiment were offspring of the second generation and were obtained from the Biomedical Laboratory, University of Southern Denmark. The rats were fitted with a radio frequency identification chip under the skin (Datamars, Lugano, Switzerland). Twenty-seven male GKmol rats, weighing $107 \pm 9 \mathrm{~g}$ and being 55-60 days old at the start of the experiment, were obtained from each of 27 litters of mother rats, which had been fed one of each of similar experimental diets as described below.

From the beginning of the experiment, the rats were housed individually in clear polyproxylene "shoebox-type" solid cages $(42 \times 26 \times 15 \mathrm{~cm})$ with stainless steel wire lids (Scanbur A/S, Lellinge, Denmark) and wood shaving bedding, in a single room controlled for temperature $\left(25 \pm 1^{\circ} \mathrm{C}\right)$ and relative humidity $(50-60 \%)$ and were

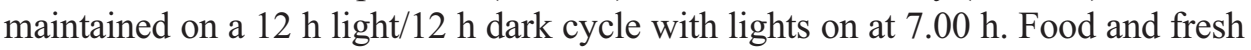
water were available ad libitum throughout the experiment.

\section{Diets}

From weaning on day 21 postpartum, rats were maintained on standard laboratory chow (Altromin no. 1324, Chr. Petersen A/S, Ringsted, Denmark), containing 190, 40 and $60 \mathrm{~g} \mathrm{~kg}^{-1}$ of protein, fat and crude fibre, respectively. The three experimental diets were based on foods produced with different cultivation strategies, intended to model some of the differences between organic and conventional farming systems. Three combinations of cultivation strategies were used: the LIminusP cultivation system had low input of nutrients through animal manure and no pesticides; the LIplusP cultivation meant low input of nutrients primarily through animal manure and as much pesticides as allowed in accordance with the Danish regulations; the HIplusP system used high input 
of nutrients through mineral fertilizer and as much pesticides as allowed. Each ingredient type was cultivated according to standard practice for the crop in terms of e.g., levels of fertilizer and timing of pesticide applications. For each crop all treatments were carried out on the same or adjacent experimental fields, which were divided according to the three cultivation strategies, so that the cultivation took place in similar soils and under similar climatic conditions, and the ingredients were harvested and treated at the same time. For all crops the LIminusP products were grown on established organic soil (more than 3 years), while the LIplusP was grown on previously organic soils for all crops except rapeseed, and the HIplusP was grown on previously conventional soil for all crops except potato and apple. For the LIminusP treatments, most of the pesticides allowed in organic agriculture (e.g., sulphur and plant extracts) were not used only a Bacillus thuringensis product was applied to the kale. All feedstuffs (potatoes, carrots, apples, peas, green kales and rapeseed oil) in the diets were produced in the experimental farms of the Danish Institute of Agricultural Sciences (DIAS). Each ingredient was treated as for human consumption, i.e. potatoes, peas and green kales were cooked, raw carrots and apples were shredded, and thereafter ingredients were freeze-dried. Rapeseed oil was produced from the air-dried rapeseeds. The nutrient composition (protein, fat, dry matter, ash, fibre, protein bioavailability, minerals, vitamins) of each ingredient was determined (Jørgensen and Lauridsen, 2004), and based on these analyses, the diets were formulated to meet or exceed NRC recommendations for growing rats (NRC, 1995), and provided as meal. The three experimental diets had exactly same formulation $\left(\mathrm{g} \mathrm{kg}^{-1}\right.$ : potatoes 300.0 , carrot 50.0, pea 472.4, green kale 10.0, apple 10.0, rapeseed oil 130.0, DL-methionine $6.4, \mathrm{CaCO}_{3} 12.5 \mathrm{~g}$, salt 0.7 , and vitamin/mineral mixture 8.0), and the diets were iso-energetic (gross energy $21.2 \pm 0.14 \mathrm{MJ} \mathrm{kg}^{-1} \mathrm{DM}$ (mean $\pm \mathrm{SD}$ ), metabolizable energy $18.0 \pm 0.14 \mathrm{MJ} \mathrm{kg}^{-1} \mathrm{DM}$ ) and iso-nitrogeneous (crude protein $160.7 \pm 0.2$ $\mathrm{g} \mathrm{kg}^{-1}$ ), and contained in addition the following main nutrients, $\mathrm{g} \mathrm{kg}^{-1}$ : dry matter $966.7 \pm 5.0, \mathrm{HCl}$-fat $156.5 \pm 1.6$, ash $41.4 \pm 0.5$, crude fibre $56.3 \pm 1.6$, dietary fibre $179.3 \pm 2.1$, calcium $6.8 \pm 0.1$, total phosphorus $3.4 \pm 0.1$, lysine $10.8 \pm 0.2$, and methionine + cysine $9.7 \pm 0.4$. The pesticide level was determined by the Regional Veterinary and Food Control Authority Copenhagen, Danish Veterinary and Food Administration, and was found to be below the detection limit. The experimental diets were mixed at DIAS, and stored at $-18^{\circ} \mathrm{C}$ before the experiment and at $4{ }^{\circ} \mathrm{C}$ during the experimental period.

\section{Preference test procedure}

Two weeks prior to testing, rats were given powdered standard laboratory chow and water ad libitum for adapting to the experimental conditions. This chow was a powdered version of their regular pellet food. After the adaptation period, the rats 
were arranged in a block design with three blocks each consisting of 9 rats. In each block there were 3 rats from mother rats fed with the three experimental diets, respectively. The data collection was performed on two subsequent experimental periods (repetition 1 and repetition 2), and in each repetition, the three blocks were tested one by one. The experimental design of the overall experiment is shown in Table 1.

TABLE 1

Experimental design of the preference test

\begin{tabular}{rclll}
\hline Age & \multirow{2}{*}{ Peek } & \multicolumn{3}{c}{ Block $(\mathrm{n}=9)$} \\
\cline { 3 - 5 } weriod & Adaptation & STD & \multicolumn{1}{c}{2} & \multicolumn{1}{c}{3} \\
\hline $4-5$ & RTD & PT & STD & STD \\
6 & R1 & STD & PT & STD \\
7 & R1 & STD & STD & PT \\
8 & Pause & STD & STD & STD \\
$9-10$ & R2 & PT & STD & STD \\
11 & R2 & STD & PT & STD \\
12 & R2 & STD & STD & PT \\
\hline
\end{tabular}

abbreviations: R1 and R2: repetition 1 and 2, i.e. the first and the second experimental period, respectively; STD: rats were fed with standard laboratory chow; PT: rats were given free and continuous access to the three experimental diets to conduct the preference test

In the five days experimental period, each rat had free access to each of the three experimental diets (LIminusP, LIplusP, HIplusP). Thereafter, the powdered standard chow was offered until the preference test was repeated. Three stainless steel feeders containing each of the three diets were placed in each cage at the same time. The amount provided of each diet increased from $15 \mathrm{~g}$ at the start of experiment (week 6) to $25 \mathrm{~g}$ at the end (week 13). Each day between 9.00 and $10.30 \mathrm{~h}$ a.m. of the experimental period, the remaining feeds were weighed and discarded, and the amount of feeds consumed was calculated. Three feeders in each cage were removed at the same time, and fresh feeds were then offered after weighing the refusals. Spillage was monitored by examining the cages without bedding during the first week, but no spillage (in 25 cages) or very little (in two cages) was found. The sequence of the feeders was changed daily in order to avoid any possible "position preference". To account for the absorption of water or evaporation during the $24 \mathrm{~h}$ of exposure, one sample of each diet served as controls in every test run. At the start and end of the experiment, individual rat body weight was measured and recorded. The Danish Animal Experiments Inspectorate, Ministry of Justice, Copenhagen, approved the protocol with the guide for the care and use of laboratory animals. 


\section{Statistical analysis}

The feed intake was analysed with an analysis of covariance incorporating correlations induced by the repeated observations on each rat. The model fitted to the data from each repetition was as follows:

$$
\omega_{d t b m}=\mu+\alpha_{d}+\beta_{t}+v_{b}+\theta_{m}+(\alpha \theta)_{d m}+\gamma B_{b m}+\varepsilon_{d t b m} .
$$

The observed dependent variable (the feed intake for diet $d$, experimental day $t$, block $b$ and mothers' diet $m$ ) is $\omega_{d t b m}, \mu$ is the overall mean, $\alpha_{d}$ is the effect of diet ( $d$ = LIminusP, LIplusP, HIplusP), $\beta_{t}$ is the effect of experimental day $(t=1,2,3$, $4,5), v_{b}$ is the effect of block $(b=1,2,3), \theta_{m}$ is the effect of mothers' diet ( $m=$ LIminusP, LIplusP, HIplusP), $(\alpha \theta)_{d m}$ is the interaction between diet and mothers' diet, $B_{b m}$ is the initial body weight of a rat, $\gamma$ the corresponding slope, and $\varepsilon_{d t b m}$ is the residual random component.

The error terms $\varepsilon_{d t b m}$ were assumed to be normally distributed, and measurements between different rats were considered to be independent. Notice that a rat is identified by a pair of the values $b$ and $m$. The repeated measurements on the same rat introduced correlations between the random errors, and the correlation structure had to be adequately modeled to obtain an appropriate evaluation of the variability of the estimates of the model parameters, e.g., the calculation of their standard errors and associated p-values. On each rat, three measurements were obtained daily during five days for each repetition. The correlation structure between the 15 measurements was constructed in three steps. First it should be noted that the measurements on the three diets on the same day were negatively correlated because eating of one diet necessarily reduced the amount eaten from the other two diets. Hence, for the same day $t$, the correlation between $\varepsilon_{d t b m}$ and $\varepsilon_{d i t m}$ for two different diets, $d$ and $d^{\prime}$, was $\operatorname{corr}\left(\varepsilon_{d t b m^{\prime}}, \varepsilon_{d^{\prime} t b m}\right)=\rho_{d d^{\prime}}$. Secondly, assuming that a rat had individual basic preferences for each of the three diets, the measurements on the same diet, $d$, on two different days, $t$ and $t$ ', had a common correlation $\operatorname{corr}\left(\varepsilon_{d t b m} \varepsilon_{d i b m}\right)=\rho$. Finally, correlations between measurements for different diets and different days were taken as the product of the above correlations, i.e. $\operatorname{corr}\left(\varepsilon_{d t b m^{\prime}}, \varepsilon_{d t^{\prime} b m}\right)=\rho \cdot \rho_{d d^{\prime}}$. This ensured that the whole correlation matrix was mathematically well defined.

The correlation $\rho$ can be interpreted as the persistency of rats to keep to a diet during one repetition. The question of persistency of the choice between the two repetitions was analysed by the correlation of the preferred diet of rats, where the preferred diet was defined as the diet of which a rat ate most during a repetition.

The decision to analyse the two repetitions separately was based on the observation that the variances of the measurements were different for the two repetitions. Additionally, the introduction of $\rho$ as the correlation across days was 
based on the assumption of a basic preference for diets by a given rat. Analysing the two repetitions separately, allowed the values of $\rho$ to be different for each repetition.

The fitting of the model was generated using the MIXED procedure of SAS/ STAT software, Version 8.2 of the SAS System for Windows (1999).

\section{RESULTS}

The majority of rats in the test showed distinct preference in one of the three experimental diets, but the preferred diet was not identical from one rat to another. The average daily intake of each of the diets performed during the five days preference test in repetition 1 was as follows (mean and SE in brackets): 5.42 (0.84), 5.46 (0.74), and $7.03 \mathrm{~g}(0.82)$ for the LIminusP, LIplusP, and LHplusP, respectively, while in repetition 2 the values were $5.59(0.95), 6.54(1.11)$ and 9.70 (1.17) $\mathrm{g}$ for the LIminusP, LIplusP, and LHplusP, respectively.

The statistical evaluation of the data is presented in Table 2. Significant interactions between diet choice and mothers diet in both repetition $1(\mathrm{P}=0.04)$ and

TABLE 2

Statistical evaluation of the food intake from the experimental diets ${ }^{1}$

\begin{tabular}{lcc}
\hline \multirow{2}{*}{ Effect } & \multicolumn{2}{c}{ P-value } \\
\cline { 2 - 3 } & repetition 1 & repetition 2 \\
\hline Diet $\times$ mothers diet & 0.04 & 0.05 \\
Experimental day & $<0.0001$ & $<0.0001$ \\
Initial body weight & 0.05 & 0.40 \\
Block & 0.33 & 0.42 \\
\hline
\end{tabular}

${ }^{1}$ the statistical model fitted to the data is described in Material and Methods

repetition $2(\mathrm{P}=0.05)$ were observed, and the effect of each interaction on the estimated feed intake is depicted in Figure 1, which shows that mutual differences between the diets changed with respect to the mothers' diet. Thus, when the mother rats were fed HIplusP, the feed intake seemed to increase in the following ranking: LIminus $\mathrm{P}<$ LIplus $\mathrm{P}<$ HIplusP. On the other hand, when rats were coming from mother rats fed LIplusP, the feed intake somehow reached a plateau, whereby the ranking was LIminusP $<$ LIplusP $\approx$ HIplusP. However, when mother rats were fed LIminusP, the rat progeny seemed to prefer the LIminusP (although the preferred food intake of the HIplusP seemed to be equal as the LIminusP in repetition 2). In other words, while mothers' diet was not LIminusP, the rats did not show preference for LIminusP, whereas rats whose mothers were fed LIminusP preferred LIminusP. However, comparison of the diet choice within a given mother diet 


\section{Repetition 1}
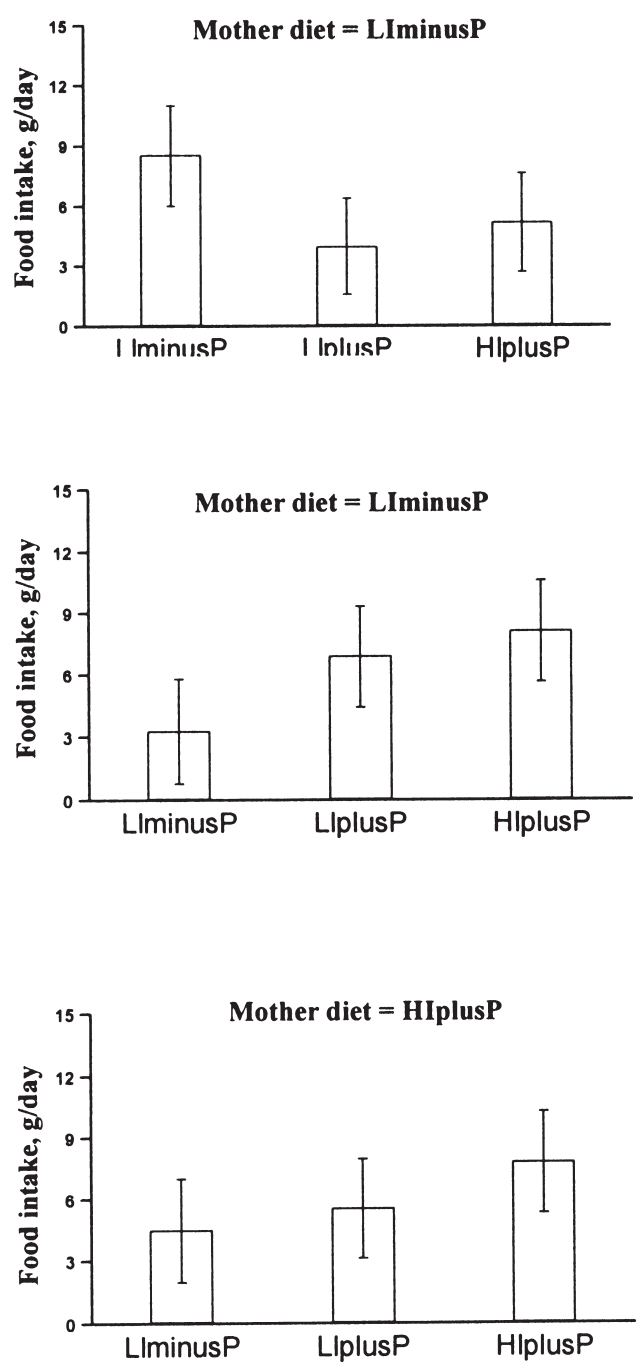

Repetition 2
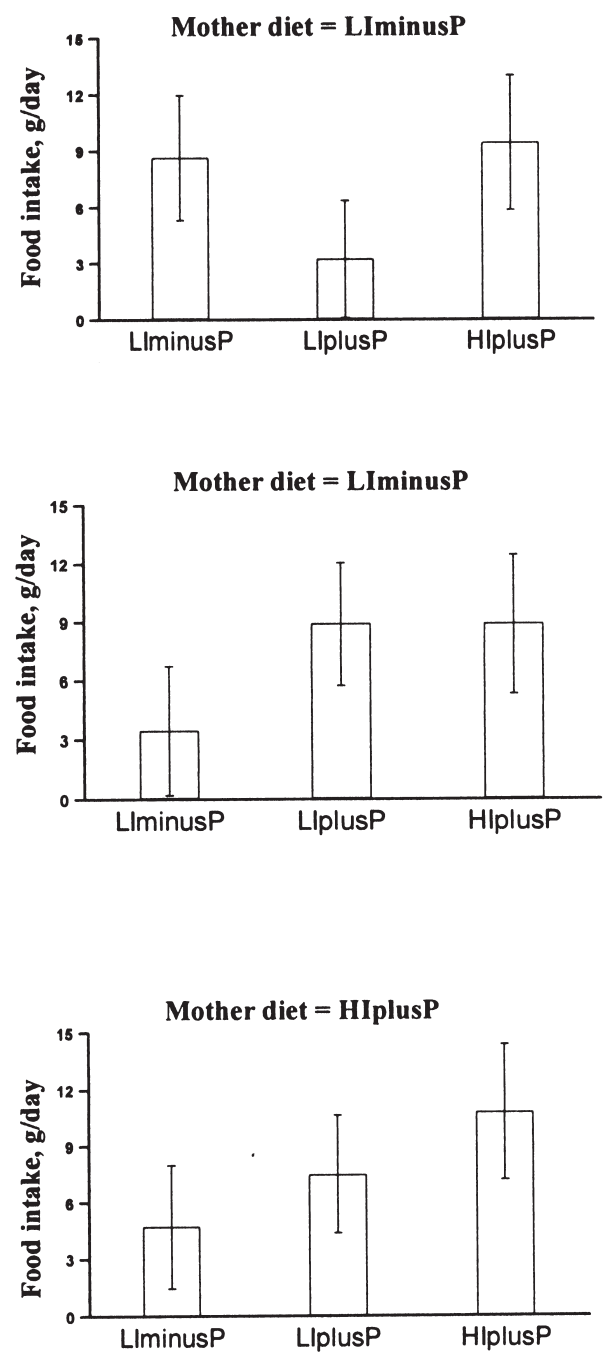

Figure 1. Interaction between effect of mothers' diets and diet choice in the food preference tests during the first experimental period (repetition 1, left, $\mathrm{P}=0.04$ ) and in the second experimental period (repetition 2, right, $\mathrm{P}=0.05$ ). LIminus $\mathrm{P}=$ low input of fertilizer without pesticides; LIplusP = low input of fertilizer and high input of pesticides; HIplusP $=$ high input of fertilizer and high input of pesticides. Repetition 1 and 2 were tested using rats of 6-8 wk age and again of 11-13 week age, respectively. The values shown are given as the least square means together with a pointwise $95 \%$ confidence interval 
and given repetition revealed minor significant differences between the three experimental diets (Figure 1; repetition 1: mother diet 1, $\mathrm{P}=0.087$; mother diet 2, $\mathrm{P}=0.071$; mother diet $3, \mathrm{P}=0.30$. repetition 2 : mother diet $1, \mathrm{P}=0.046$; mother diet $2, \mathrm{P}=0.074$; mother diet $3, \mathrm{P}=0.133$ ).

The overall statistical evaluation of the feed intake also showed (Table 2) a strong significant effect of the experimental day in both repetition $1(\mathrm{P}<0.0001)$ and repetition $2(\mathrm{P}<0.0001)$, and the feed intake was influenced by the initial body weight in repetition $1(\mathrm{P}=0.05)$.

The analysis of the correlation between the two repetitions indicated that there was a high tendency of persistency on choice of the diets (Kendall's $\tau=0.79$ meaning that the rats behaved similarly in the two repetitions of the experiment). The high correlation of feed intake for the same diet across experimental days $(\rho=0.63$ in repetition 1 and $\rho=0.73$ in repetition 2) showed a strong general tendency to stay with one diet (Table 3 ). The negative correlations between the feed intake of different diets in a rat on the same experimental day $\left(\rho_{d d^{\prime}}\right.$, between -0.52 and -0.26$)$ reflected merely the fact that the decision for one diet rendered the rejection of the other diets (Table 3).

TABLE 3

Correlation analysis of the food intake of a rat ${ }^{\mathrm{a}}$

\begin{tabular}{|c|c|c|}
\hline Correlation & Repetition 1 & Repetition 2 \\
\hline$\rho$ & 0.63 & 0.73 \\
\hline$\rho_{\text {LIminus } P \text { LIplus } P}$ & -0.40 & -0.26 \\
\hline$\rho_{\text {LIminus } P \text { P.HIflus } P}$ & -0.51 & -0.52 \\
\hline$\rho_{\text {LIplus } P \text { HIplus } P}$ & -0.46 & -0.47 \\
\hline
\end{tabular}

${ }^{a}$ the $\mathrm{p}$-values for the hypothesis that a parameter was zero were $<0.01$ for all parameters. $\rho$ : A common correlation between the intake of a given diet on different experimental days. $\rho_{d, d^{\prime}}\left(\rho_{\text {LIminus } P \text { LIplus } P} \rho_{\text {LIminusP,HIplus } P} \rho_{\text {LIplus } P \text {,HIplusP }}\right)$ : Correlation between the intake of different diets of a rat on the same experimental day. The details of the statistical method are described in Material and Methods

\section{DISCUSSION}

Feed preference tests of products from different cultivation systems with different animals (hens, rabbits, mice, rats) have shown that in five out of six studies, it was obvious that the test animals preferred organically to conventional products (Woese et al., 1997). However, the reason for this preference is not known. Possible arguments have been different taste and compensatory consumption to balance the lower crude protein content often reported in organic products (Neudecker, 1987). However, Plochberger and Velimirov (1992) showed that rats preferred organically grown feed compared with conventionally grown feed even 
when both feed types met the physiological needs of the test animals. It is wellknown that a rat can select from available feed to meet its needs (Fromentin and Nicolaidis, 1996). In order to make a reliable comparison, the present study was undertaken with iso-energetic and iso-nitrogeneous diets to investigate if rats were able to distinguish between diets of different cultivation systems. The majority of rats showed individual preference on one of the three diets, but the preferred diet was not uniform from one rat to another. When considering the average feed intake, aggregated for experimental periods and mother rats' diets, the HIplusP seemed to be preferred to the other two diets. However, the statistical analyses of the data showed a more varied result as discussed below.

Benett and Henderson (1972) found that weanlings actively seek and preferentially ingest the diet their mothers ate during the nursing period, even if that diet was relatively unpalatable. Accordingly, our data showed an interesting result as the predicted consumption of LIminusP was the lowest of the three diets if the mothers' diets were HIplusP or LIplusP. However, if the mothers' diet was LIminusP, the LIminusP diet was among the preferred diets by the rats. The observed influence of the mother rats' diets on the diet choice of the progeny might be explained by either an influence of the dietary treatments on the composition of the rat milk, or that the progeny nibbled from the feed troughs during the suckling period or a combination of the two factors. Thus, despite the provision of powdered standard laboratory chow prior to testing, and the pause between the two repetitions of the preference test, rats' feed choice was influenced by the mother rats' dietary treatment, and it cannot be excluded that the cultivation methods influenced some specific palatability components of the feed, which were recognized by the progeny once they had been introduced to the diets during the suckling period. Due to the authors' knowledge very few studies have considered the effect of the maternal diet when comparing rats' choice of diets from different cultivation systems, and further research is needed to clarify the relationship between the cultivation system and the nutritional quality of crops in order to explain the interaction between the food choice made by the progeny and the mothers' dietary treatment.

Our data showed that nearly all rats behaved similarly in the two experimental periods, which meant that the four-week pause did not change the food option of rats. The result suggests that the laboratory rat has the capability or biological instinct to insist on the diet choice. The short-term choice of food is influenced by neophilia, odour, taste, texture and palatability, whereas the long-term preference of food is determined by its physiological effect (Plochberger and Velmirov, 1992). In another experiment to be reported elsewhere (Lauridsen C., personal communication), the diets used in the present preference test was compared with regard to their long-term physiological effect on rats of similar breeding origin.

In this investigation, many rats showed individual preference for the experimental diets, but totally no clear difference among the dietary treatments 
could be obtained, as our data showed preferences conditional on mothers' dietary treatments. The present study could therefore not support some of the previous reports (Plochberger and Velmirov, 1992; Mäder et al., 1993; Malheiros et al., 2003) concluding that rats prefer organic feeds to conventional ones.

It must be recognized that there were very large deviations in the present study, because the diet choices of rats were different from one individual rat to another and were changed from one experimental day to another. A large variability was also identified in other studies with different animal species, e.g., mice (Benett and Henderson, 1972), rats (Johnson and Collier, 2001) and broiler chickens (Malheiros et al., 2003), and may be linked to variability in individual needs and influenced by behavioural factors, such as adaptation, learning capabilities, and social interactions (Benett and Henderson, 1972; Malheiros et al., 2003). Probably the large variation in the present study was the reason why comparisons of the diet choice (Figure 1) revealed only minor significant differences.

This trial using iso-energetic and iso-nitrogeneous diets of three different cultivation systems showed that rats had individual preference among the diets, and that the diet choice of the progeny was conditional on the maternal dietary treatment. Therefore no definitive conclusion could be drawn with regard to the selection of food from one cultivation system in preference to food of another.

\section{ACKNOWLEDGEMENTS}

The authors thank Kathrine Hansen Hoirup and Benny Thomasen for their valuable technical assistance in performing this study.

\section{REFERENCES}

Benett B.G., Henderson P.W., 1972. Mothers milk - determinant of feeding preferences of weaning rat pups. J. Comp. Physiol. Psychol. 78, 213-219

Brandt K., Mølgaard J.P., 2000. Organic agriculture: does it enhance or reduce he nutritional value of plant foods? J. Sci. Food. Agr. 81, 924-931

Fromentin G., Nicolaidis S., 1996. Rebalancing essential amino acids intake by self-selection in the rat. Brit. J. Nutr. 75, 669-682

Johnson D.F., Collier G., 2001. Taste, intake rate, and food choice in rats. Physiol. Behav. 72, 37-44

Jørgensen H., Lauridsen C., 2004. Nutrient composition and bioavailability of protein and energy in common fruits and vegetables prepared for human consumption. In: Challenges to Food Science and Technology. Abstract Collection, Food Congress, Danish Technical University, p. 135

Koehnle T.J., Russell M.C., Gietzen D.W., 2003. Rats rapidly reject diets deficient in essential amino acids. J. Nutr. 133, 2331-2335

Mäder P., Pfiffner L., Niggli U., Balzer U., Balzer F., Plochberger K., Velimirov A., Besson J.M., 1993. Effect of three farming systems (bio-dynamic, bio-organic, conventional) on yield and quality of beetroot (Beta vulgaris 1. var. esculenta 1.) in a seven year crop rotation. Acta Hortic. 339, 1-31 
Malheiros R.D., Moraes V.M.B., Collin A., Decuypere E., Buyse J., 2003. Free diet selection by broilers as influenced by dietary macronutrient ratio and corticosterone supplementation. 1. Diet selection, organ weights, and plasma metabolites. Poultry Sci. 82, 123-131

Neudecker C., 1987. Düngung und Qualität von Lebensmitteln-Tierfütterungsversuche mit mineralish und organish gedüngten Katoffeln und Möhren. In: Landbaumethoden und Nahrungsqualität (Materialen und Berichte Nr. 60). Akademie für Politische Bildung, Tutzing (Germany), pp. $110-125$

NRC, 1995. Nutrient Requirements of Laboratory Animals. National Academy Press. Washington, DC Pfeiffer E., 1969. Die Fruchtbarkeit der Erde. 5. erw. Auflage. Rudolf Geering Verlag, Dornach, pp. 331

Plochberger K., 1989. Feeding experiments - a criterion for quality estimation of biologically and conventionally produced foods. Agr. Ecosyst. Environ. 27, 419-428

Plochberger K., Velmirov A., 1992. Are food preference tests with laboratory rats a proper method for evaluating nutritional quality? Biol. Agric. Hortic. 8, 221-233

SAS/STAT Users's Guide, 1999. Version 8, Cary, NC: SAS Institute Inc.

Schifferstein H.N.J., Ophuis P.A.M.O., 1998. Health-related determinants of organic food consumption in the Netherlands. Food Qual. Preference 9, 119-133

Warman P.R., Havard K.A., 1997. Yield, vitamin and mineral contents of organically and conventionally grown carrots and cabbage. Agr. Ecosyst. Environ. 61, 155-162

Williams C.M., 2002. Nutritional quality of organic food: shades of grey or shades of green? Proc. Nutr. Soc. 61, 19-24

Wolfson J.L., Shearer G., 1981. Amino-acid-composition of grain protein of maize grown with and without pesticides and standard commercial fertilizers. Agron. J. 73, 611-613

Woese K., Lange D., Boess C., Bogl K.W., 1997. A comparison of organically and conventionally grown foods - results of a review of the relevant literature. J. Sci. Food Agr. 74, 281-293

Worthington V., 1998. Effect of agricultural methods on nutritional quality: a comparison of organic with conventional crops. Alt. Therapies Health Med. 4, 58-69

\section{STRESZCZENIE}

\section{Dieta matek wpływa na indywidualną preferencję szczurów w stosunku do diet zawierających rośliny uprawiane w różnych warunkach nawożenia i traktowania pestycydami}

Przygotowano trzy diety zawierające produkty roślinne pochodzące z trzech systemów uprawy: mała ilość nawozów bez pestycydów ( $\alpha$ I minus P), mała ilość nawozów, duża ilość pestycydów ( $\alpha$ I minus P) oraz duża ilość nawozów i pestycydów (HI plus P). Przeprowadzono testy preferencji w celu stwierdzenia czy szczury rozróżniają te diety oraz czy na ich wybór wpływa rodzaj diety, którą były żywione matki. Diety doświadczalne zawierały ziemniaki, marchew, groch, włoską kapustę, jabłka i olej rzepakowy, były izo-białkowe i izoenergetyczne i pokrywały zapotrzebowanie rosnących szczurów wg NRC.

Doświadczenie przeprowadzono na 27 szczurach odsadzonych od matek żywionych jedna z trzech diet doświadczalnych. Po 2-tygodniowym okresie żywienia dietą hodowlaną szczurom przez 5 dni podawano do woli kolejno każdą z trzech diet i mierzono ich spożycie. Następnie wszystkie szczury żywiono dietą hodowlaną i test preferencji powtórzono. Wyniki wskazują że większość szczurów wykazywała indywidualną preferencję w stosunku do ocenianych diet i zachowywała się podobnie $\mathrm{w}$ różnych dniach doświadczenia $\rho=0,63 \mathrm{w}$ powtórzeniu 1 i $\rho=0,73 \mathrm{w}$ powtórzeniu 2 oraz $\mathrm{w}$ obydwóch powtórzeniach $\mathrm{r}=0,79$. Wystapiła istotna interakcja między wyborem diety a dietą matki ( $\mathrm{P}=0,04 \mathrm{w}$ powtórzeniu 1 i $\mathrm{P}=0,05 \mathrm{w}$ powtórzeniu 2$)$ : gdy matki jadły dietę $\alpha \mathrm{I}$ minus $\mathrm{P}$, dieta ta należała do diet preferowanych przez potomstwo. Natomiast potomstwo matek żywionych dietą $\alpha$ I plus P lub HI plus P zjadało najmniej diety $\alpha$ I minus P. 